of the association which has been held to exist between the philosophical theory of determinism on one hand, and the scientific view of the world on the other. When a coin is tossed, we say that whether it comes down heads or tails is a matter of 'chance'. This does not mean that there is any real indetermination in the occurrence; but merely that we cannot make a confident prediction, because we do not know the precise velocities of translation and rotation which were communicated to the coin by the thumb of the operator, or the exact mass and figure of the coin, or the density and resistance of the air. If these, and the other relevant data which are unknown to us, are called the 'hidden parameters', then an imaginary person to whom the values of the hidden parameters were correctly known would be able, by aid of the laws of dynamics, to calculate mathematically all the circumstances of the flight and to determine whether the coin would fall heads or tails.

Phenomena of this kind, which are in reality deterministic, although we cannot foretell their outcome because of our lack of information regarding hidden parameters, may be called 'erypto-deterministic'. Wherever the notion of 'chance' occurs in classical physics, it has the crypto-deterministic sense. It is otherwise in the newer atomic physics. The alpha-particles emitted by a small quantity of radium salt may be observed by means of the scintillations they produce on a fluorescent screen, and these scintillations appear at irregular intervals-it is impossible to predict the instant when any particular radium atom will explode. By a quantummechanical examination, Prof. Whittaker showed that this phenomenon cannot be crypto-deterministic, but involves a true indetermination. Thus the world is not a closed deterministic system but experiences a continual succession of intrusions or fresh creations. The relation of this to certain ideas in Greek philosophy was discussed, and its bearing on the formulation of the law of causality and on the problem of freewill.

\section{English Scientific Film Association}

As English Scientific Film Association was formed on May 15, at a meeting representative of science and films, convened by the Scientific Films Committee of the Association of Scientific Workers. Mr. Arthur Elton was in the chair. He stated that the new association would be independent and selfgoverning. An Interim Planning Committee was appointed to frame the constitution and to propose conditions of membership. Contact has already been made with the equivalent Scottish association. The acting secretary is Mr. M. Michaelis, 51 Fitzjohn's Avenue, London, N.W.3. The main aims of the new Association are : to promote the national and international use of the scientific film in order to achieve the widest possible understanding and appreciation of scientific methods and outlook, especially in relation to social progress; and to collect, collate and distribute information on the scientific film, including possibly the formation of a reference library of books and the publication of a journal and pamphlets. The Association will publish coms prehensive lists of scientific films graded according to scientific merit. It hopes to establish relations with Government departments, public bodies and other organizations which are in a position to make, use or circulate scientific films. A representative panel of scientific workers, to advise producers of films of all types on seientific matters in connexion with their films and to maintain close contact with the film industry, will be compiled.

\section{The Work of Copernicus}

Prof Herbert Dingle writes: "Might I correct a small error, for which I am partly responsible, in the report of my address on Copernicus printed in Nature of May 22 ? Luther did not 'predict' that Copernicus would overturn astronomy. His words were : 'Der Narr will die ganze Kunst Astronomiae umkehren' ; that is, 'The fool wishes to overturn the whole science of astronomy'. There is no reason to suppose that Luther thought he would succeed.

\section{Comet Whipple-Fedtke}

THIs comet is fading rapidly and on April 13 its magnitude was $8 \cdot 5$. An ephemeris is given for June.

June $1 \cdot 0 \mathrm{~d}$.
5
9
13
17
21
25
29

$\begin{array}{ll} & \text { R.A. } \\ \text { 13h. } 12 \cdot 4 \mathrm{~m} . \\ 13 & 15 \cdot 7 \\ 13 & 19 \cdot 0 \\ 13 & 22 \cdot 4 \\ 13 & 26 \cdot 0 \\ 13 & 29 \cdot 6 \\ 13 & 33 \cdot 4 \\ 13 & 37 \cdot 3\end{array}$

$$
\begin{gathered}
\text { Dec. } \\
+21 \cdot 1^{\circ} \\
19 \cdot 6 \\
18 \cdot 2 \\
16 \cdot 7 \\
15 \cdot 4 \\
14 \cdot 1 \\
12 \cdot 8 \\
11 \cdot 5
\end{gathered}
$$$$
\begin{array}{r}
\rho \\
1.456 \\
.523 \\
.593 \\
.664 \\
.738 \\
.813 \\
.891 \\
.969
\end{array}
$$$$
\begin{gathered}
r \\
2 \cdot 097 \\
\cdot 137 \\
\cdot 177 \\
.218 \\
.258 \\
.299 \\
.340 \\
.381
\end{gathered}
$$

\section{The Night Sky in June}

NEw moon occurs on June 2d. 22h. 33m. U.T. and full moon on June 18d. 05h. 14m. The following conjunctions with the moon will take place: June 1d. 19h., Mercury $1^{\circ}$ N. ; June 6d. 14h., Jupiter $2^{\circ}$ N. ; June 7d. 00h., Venus $4^{\circ}$ N.; June 26d. 05m., Mars $3^{\circ}$ N. ; June 30d. 19h., Saturn $3^{\circ}$ N. ; June 30d. 21h., Mercury $3^{\circ} \mathrm{N}$. Occultations are very few during the month and only one is worth noticing: June $16 \mathrm{~d}$. Ih. $26 \cdot 0 \mathrm{~m} ., \gamma$ Lib. (D). Mercury is stationary on June 4 and attains its greatest elongation west on June 18, and on this date rises at $3 \mathrm{~h}$. Venus attains its greatest elongation east on June 28 and sets then at $22 \mathrm{~h} .40 \mathrm{~m}$. Mars is moving northward into the constellation of Pisces and rises at $1 \mathrm{~h}$. about the middle of the month but cannot be observed very conveniently. Jupiter sets at $22 \mathrm{~h}$. $20 \mathrm{~m}$. in the middle of the month and can be seen for only a comparatively short period after sunset. Saturn is in superior conjunction with the sun on June 7 and cannot be observed. Summer Solstice is on June 22d. 07h.

\section{Announcements}

THE King has been pleased to command that the Institute of Chemistry shall henceforth be known as "The Royal Institute of Chemistry of Great Britain and Ireland".

The thirteenth Thomas Young Oration will be delivered before the Physical Society by Prof. F. C. Bartlett on June 4 at 5 p.m., in the lecture theatre of the Science Museum, South Kensington. Prof. Bartlett will speak on "Some Current Problems in Visual Functions and Visual Perception".

THE British Coal Utilization Research Association is arranging an open conference on "The Ultra-fine Structure of Coals and Cokes, with Special Reference to the Application of Modern Physical Methods", to be held at the Royal Institution during June 24-25. Forms of applications to attend, which are issued free of charge, can be obtained from the Conference Secretary, B.C.U.R.A., Rickett Street, West Brompton, London, S.W.6, to whom they should be returned by June 4. 